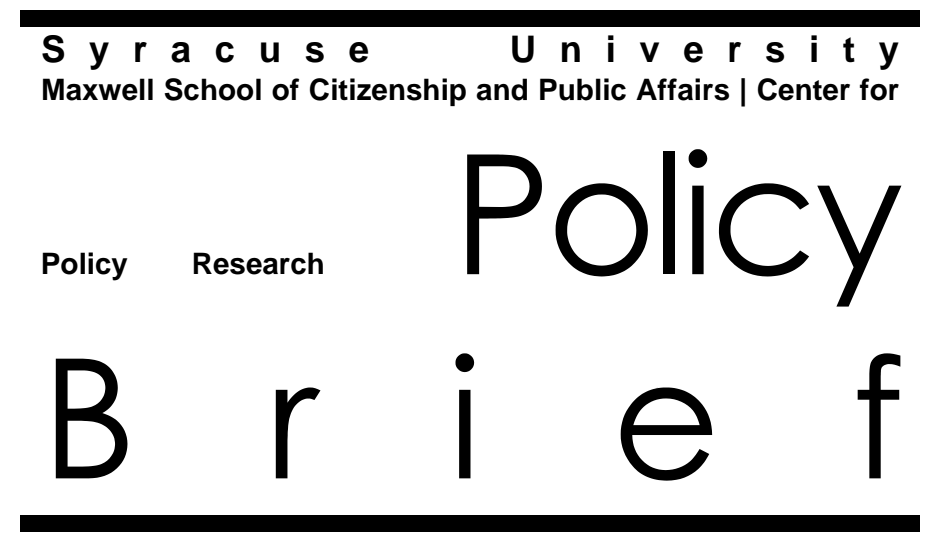

Social Security Reform:

A Budget Neutral Approach to

Reducing Older Women's

Disproportionate Risk of Poverty

Richard V. Burkhauser and

Timothy M. Smeeding

No. 2/1994 
Richard V. Burkhauser, Ph.D., Professor of Economics, is Associate Director for the Aging Studies Program, Center for Policy Research, and Director of the All-University Gerontology Center. $\mathrm{He}$ is also principal investigator for an NIA-funded study of the well-being of the elderly in a comparative context.

Timothy M. Smeeding, Ph.D., Professor of Economics and Public Administration, is Director of the Center for Policy Research. He has also been Project Director for the Luxembourg Income Study (LIS), a database development and research project funded by a multi-nation consortium of national science and research foundations, since its inception in 1983.

This report was funded in part by the National Institute on Aging, Program Project \#1-P01AG09743-01, "The Well-Being of the Elderly in a Comparative Context." The views expressed here are solely those of the authors and do not reflect the official position of the National Institute on Aging.

The Policy Brief series is a collection of essays on current public policy issues in aging, health, income security, metropolitan studies and related research done by or on behalf of the Center for Policy Research at the Maxwell School of Citizenship and Public Affairs.

Single copies of this publication may be obtained at no cost from the Center for Policy Research, Maxwell School, 426 Eggers Hall, Syracuse, NY 13244-1090.

C 1994 , Syracuse University 
Policy Brief

Social Security Reform:

A Budget Neutral Approach to Reducing Older Women's Disproportionate Risk of Poverty

Richard V. Burkhauser and Timothy M. Smeeding 


\section{Social Security Reform:}

\section{A Budget Neutral Approach to Reducing Older Women's Disproportionate Risk of Poverty}

\section{Richard V. Burkhauser and \\ Timothy M. Smeeding}

People share a common fear of a substantial decline in economic well-being, or even worse, a fall into poverty. Work in the marketplace is the principal source of income in modern societies, and the transition from work to retirement can be fraught with economic risks. Hence, it is not surprising that all post-industrialized societies have developed sophisticated social and private institutions to mitigate these risks.

Perhaps the single greatest achievement of social policy in the United States over the last three decades has been reducing poverty in old age. The transition from work to retirement is no longer economically perilous for the vast majority of older American workers. For most married couples, the risk of falling into poverty even several years after retirement is small. But when one partner of the marriage dies, the survivor faces another much more risky economic transition. The single greatest risk of falling into poverty in old age now comes after the death of a spouse, as the survivor faces life after marriage. And this risk disproportionately affects older women, who are nearly three times as likely as older men to be widowed (49 percent to 14 percent) and can expect to remain widowed an average of 17 years (Population Resource Center 1994).

Here we document the disproportionate risk of poverty faced by such survivors and show that the Social Security system in the 


\section{Aging Studies Program Policy Brief}

United States has been much less successful in protecting single older people from poverty, especially single older women, than government-administered Social Security systems in other postindustrialized countries. We argue that this lack of success stems in part from the failure of the Social Security program to transform the basis for its payout rules from a "traditional" oneearner family model to a model more consistent with today's families in which both the husband and wife work. We then offer a budget neutral plan to redistribute some of the benefits a married couple receive over their lifetime from the years whey they are both alive to the years following the death of a spouse, which we argue would substantially reduce the risk of poverty faced by older women.

\section{Insuring Economic Well-Being in Retirement: Successes and Failures}

A major success story in federal policy over the last three decades has been the dramatic improvement in the economic well-being of the aged (Quinn and Smeeding 1993; Smolensky, Danziger, and Gottschalk 1988). Formerly, retirement from the workforce was closely linked to a substantial decline in income and an increased risk of poverty. However, the poverty rate for people aged 65 and older has dropped from more than one in three in 1959 to about one in eight by 1992. As recently as 1970, older people were more than twice as likely to be poor as people under age 65. Since 1982 those aged 65 and older have been on average less likely to live in poverty than younger people (U.S. Congress 1994). This transformation is especially remarkable because it occurred at the same time that the average retirement age of men fell from 65, the so-called "normal retirement" age, to 62 (Quinn and Burkhauser 1994). Hence, most newly retiring men are receiving up to 20 percent less in yearly Social Security benefits than they would receive if they had waited until age 65 to retire. 
Burkhauser \& Smeeding

Both these phenomena are largely explained by substantial increases in the retirement benefits paid by our public and private retirement systems. In the 1970 s, changes in the benefit calculation rules led to an increase in inflation-adjusted Social Security benefits of more than 50 percent. In addition, in 1974 the federal Supplemental Security Income program replaced state old-age assistance programs and established a minimum, cost-ofliving-adjusted income floor for everyone aged 65 and older. These increases in government support for the elderly were matched by a substantial increase in the scope and availability of employer pension plans. Growth of the public and private components of our retirement system significantly improved the economic well-being of older people and strongly encouraged workers to retire at earlier ages (Anderson, Burkhauser, and Quinn 1986; Ippolito 1989; Quinn, Burkhauser, and Myers 1990).

But the overall economic improvement at older ages captured by comparing statistical averages obscures wide differences in economic well-being within the population of older people as well as the disproportionate risks of falling into poverty faced by older women (Quinn 1989; Smeeding 1986). Ironically, the very success of our retirement system in easing the initial transition from work to retirement may have increased those risks, especially for women. As we will see, Social Security does an excellent job of providing income to married men and women but is far less successful in assuring the same level of well-being to the survivors of those marriages, the vast majority of whom are women.

Table 1 provides information on the poverty status of older women and men of different ages and marital status. It shows the wide range of economic well-being within the older age population. In general, women and men aged 75 and older have a higher risk of poverty than those aged 65 to 74, and older married couples are much less likely to live in poverty than are non- 
Aging Studies Program Policy Brief

Table 1. Relative Poverty Rates of Older Women and Men in the United States in $1992^{\mathrm{a}}$

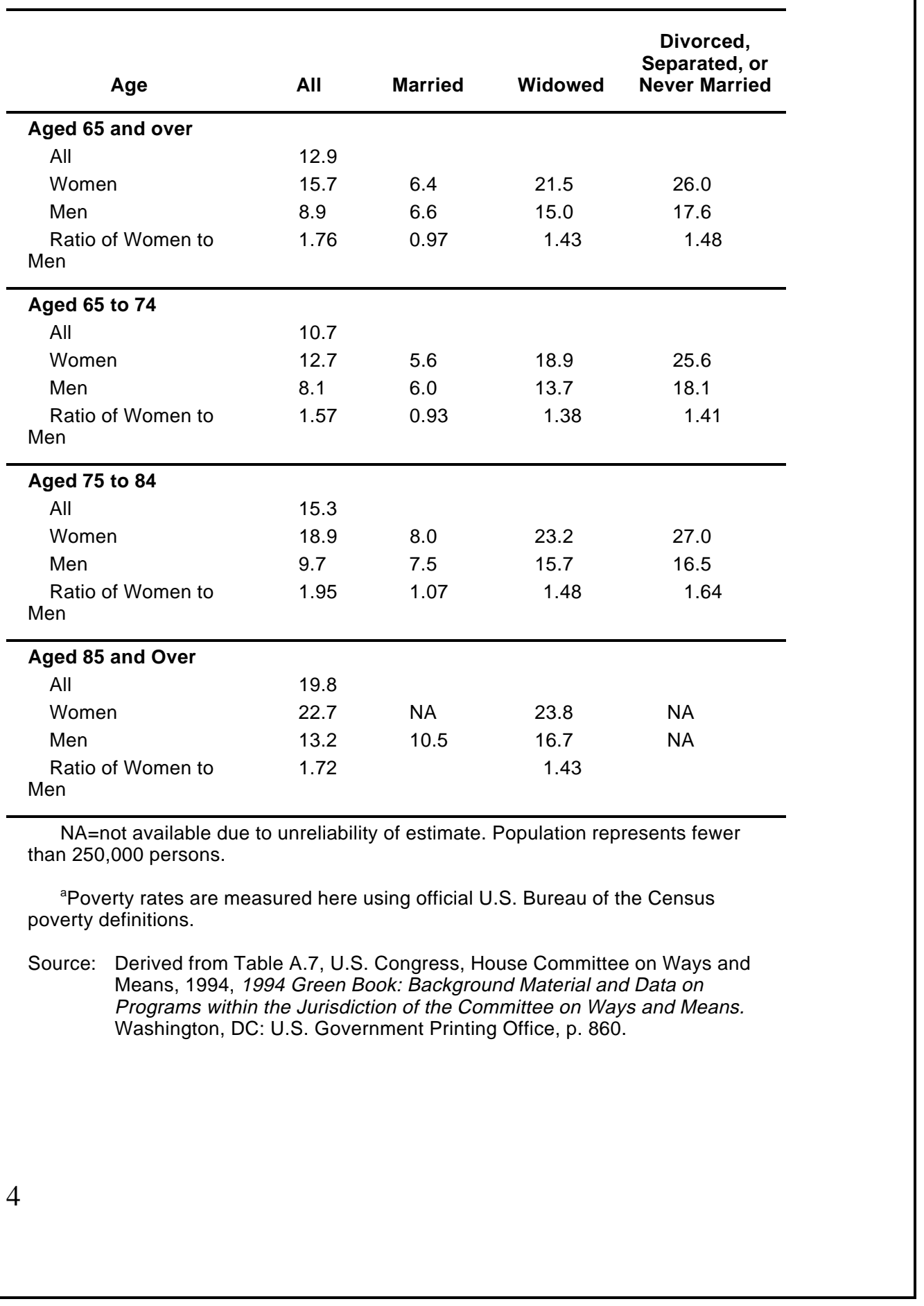


married older people. But what is most striking in the table is the disproportionate risk of poverty faced by women.

Older women are 76 percent more likely to be poor than older men-15.7 percent versus 8.9 percent. Overall, older women are more likely to be in poverty than older men because

- when they are not sharing resources with a man in marriage, the ratio of female to male poverty exceeds 1.00 ;

- among older people, the average woman is older than the average man; and

- at all ages women are less likely to be married.

Hence, women have higher poverty risks within each age-marital state, except when married, and they also dominate the agemarital states associated with a higher risk of poverty. It is this wide disparity between the economic well-being of older women and men that constitutes the most pressing unfinished business of social policy toward the aged.

\section{A Cross-National Perspective}

Among older persons in the United States the risk of poverty is substantially greater for those over age 75 , for the non-married, and for women. A comparison of the United States and seven other post-industrialized nations in Table 2 shows that neither the absolute size of the older poverty population nor the disproportionate risk of poverty of older women is inevitable. Rather, the absolute and relative poverty risk faced by older nonmarried women in the United States is considerably higher than in any other country in our sample.

As can be seen in Table 2, in the United States, the 6.0 percent 
poverty rate of older married households was well below the 13.5 percent poverty rate of younger households in 1986, while the 17.6 percent poverty rate for older non-married women was well above it. Furthermore, there was a wide difference between the poverty rates of older non-married women and older married couples in the United States-17.6 percent versus 6.0 percent, or 11.6 percentage points.

This pattern of both higher absolute and higher relative poverty of non-married women is unique to the United States. In every country shown in Table 2 except Germany, the most recent poverty rate of older non-married women as well as of older couples is below the poverty rate of younger households. Hence, non-married older women in the United States are not only the poorest group among the aged in these post-industrialized countries, they are also the only group with poverty rates significantly higher than both those of the nonaged population and the older married population of their country.

Only in the United States, Germany, and Canada are older women who live alone substantially worse off than older couples. However, the difference is smaller in Germany and Canada, as is the level of poverty. In Sweden, the Netherlands, France, and the United Kingdom, poverty rates for both older groups are very low and nearly equal. In Australia, non-married older women actually have a lower poverty rte than do older couples, though the difference- 0.4 percentage points-is quite small. In the last column of Table 2 we show that older non-married women in the United States have a poverty rate from 3 to more than 40 times as high as their counterparts in the other post-industrialized countries in our sample.

\section{The Treatment of Survivors by Social Security}

The disparity between the economic well-being of married and 
Table 2. Poverty Rates by Age and Household Type across Modern Post-Industrialized Countries ${ }^{a}$

\begin{tabular}{|c|c|c|c|c|c|c|}
\hline \multirow[b]{2}{*}{ Country } & \multirow[b]{2}{*}{ Year } & \multirow[b]{2}{*}{$\begin{array}{c}\text { Aged } 64 \\
\text { and Under }\end{array}$} & \multicolumn{3}{|c|}{ Aged 65 and Over } & \multirow[b]{2}{*}{$\begin{array}{c}\text { Ratio of Poverty } \\
\text { Rates for Non- } \\
\text { Married Women: } \\
\text { United States to } \\
\text { Other }\end{array}$} \\
\hline & & & $\begin{array}{l}\text { Non-married } \\
\text { Women } \\
\text { (A) }\end{array}$ & $\begin{array}{l}\text { Married } \\
\text { Couples } \\
\text { (B) }\end{array}$ & $\begin{array}{c}\text { Difference in } \\
\text { Poverty Rates within } \\
\text { Older Population } \\
\text { (A-B) }\end{array}$ & \\
\hline \multirow[t]{2}{*}{ United States } & 1979 & 13.4 & 21.5 & 8.1 & 13.4 & na \\
\hline & 1986 & 13.5 & 17.6 & 6.0 & 11.6 & na \\
\hline \multirow[t]{2}{*}{ Canada } & 1981 & 9.0 & 7.5 & 1.8 & 5.7 & 2.9 \\
\hline & 1987 & 8.9 & 3.2 & 0.6 & 2.6 & 5.5 \\
\hline \multirow[t]{2}{*}{ Australia } & 1981 & 6.8 & 2.3 & 3.2 & -0.9 & 9.3 \\
\hline & 1985 & 7.2 & 3.8 & 4.2 & -0.4 & 4.6 \\
\hline Germany & 1981 & 2.4 & 7.0 & 4.2 & 2.8 & 3.1 \\
\hline \multirow[t]{2}{*}{ Sweden } & 1981 & 5.4 & 0.0 & 0.0 & 0.0 & c \\
\hline & 1987 & 7.7 & 1.7 & 0.2 & 1.5 & 10.3 \\
\hline \multirow{2}{*}{$\begin{array}{l}\text { United } \\
\text { Kingdom }\end{array}$} & 1979 & 2.4 & 3.2 & 0.0 & 3.2 & 6.7 \\
\hline & 1986 & 3.1 & 0.4 & 0.9 & -0.5 & 44.0 \\
\hline \multirow{2}{*}{$\begin{array}{l}\text { The } \\
\text { Netherlands }\end{array}$} & 1983 & 6.1 & 5.8 & 1.5 & 4.3 & 3.7 \\
\hline & 1987 & 5.8 & 0.0 & 0.0 & 0.0 & c \\
\hline \multirow{2}{*}{ France } & 1979 & 6.0 & 0.5 & 1.1 & -0.6 & 43.0 \\
\hline & 1984 & 6.2 & 0.8 & 0.7 & 0.1 & 22.0 \\
\hline
\end{tabular}

a Poverty rates are measured as the percentage of poor in each type of household where poverty is measured as household sizeadjusted income below 40 percent of the country's median household size-adjusted income using an equivalence scale that counts the first person at 1.0 and all subsequent persons at .5. 


\section{Aging Studies Program Policy Brief}

non-married Americans in their retirement years that we report in Tables 1 and 2 might not be a serious problem if the period of widowhood or divorce in this country were relatively short. But two important social phenomena have combined to lengthen this time period for older women and thus exacerbate the disparity.

- Increased life expectancy of women relative to men. In the United States, one-third of all women are widowed by the time they reach age 65 . More than half are widowed by age 75 . At age 85 , more than two-thirds are widows. Furthermore, the expected years of widowhood for such women are far more than the four year difference in life expectancy between women and men at these ages since most women marry older men. A 65-year-old widow can anticipate living another 18 years. Women widowed at age 70 have a life expectancy of 11 years, and 9 years at age 85 . For younger wives, widowhood will be even longer. It is estimated that women will on average spend 17 years as a widow (Population Resource Center 1994; Siegel and Taeuber 1986).

- Decreased retirement age of men, discussed earlier. This, together with the extension of the period between the death of a husband and the death of his spouse, has increased the total number of years a woman will spend in retirement, both as a wife and widow. For example, by the year 2010, a man reaching age 62 is projected to live an additional 18 years. If he dies at age 80 , his widow, if she is the same age, can expect to live another 11 years. She will thus live in retirement for a total of 29 years. Hence, at retirement this 62-year-old couple must estimate consumption needs for a period of almost 30 years and try to make appropriate decisions about the allocation of their resources. 
Therefore, social policymakers must consider not only how wellbeing changes as households move into retirement but also how it changes in the years after retirement and especially after the death of a spouse. Burkhauser, Butler, and Holden (1991) used data from the Retirement History Survey to trace the economic wellbeing of married couples following the husband's retirement. Using hazard modeling techniques, they showed that the risk of falling into poverty decreases over time for couples who survive over the period of the analysis (1969-1979). The same is true for the households of widowers. But for households of widows not only does the risk of falling into poverty not decrease over time, it dramatically increases following the death of a spouse.

Part of the reason for this increase stems from rules governing our Social Security system. The Social Security Act was passed in 1935 and amended to include benefits for survivors and dependents in 1939. At that time, the one-earner family was the norm. The husband worked in the marketplace and the wife worked at home. Work patterns have changed dramatically since then, but Social Security payout rules have not. This has led to serious inequities between two- and one-earner households, which become more pronounced after the death of a spouse.

Table 3 compares two couples with identical combined Social Security-covered average yearly earnings of $\$ 60,600$, but with a different division of earnings between the wife and the husband. The first couple, in which all earnings are the husband's, receives a total Social Security benefit of $\$ 21,600$ per year. The retired worker is paid $\$ 14,400$ and his wife receives a spouse benefit equal to one-half of her husband's retired-worker benefit. After his death, the widow receives the husband's worker benefit of $\$ 14,400$ in place of her spouse benefit. Note that for this "traditional family" the survivor benefit is two-thirds of the total amount previously paid to the couple. 
Aging Studies Program Policy Brief

Table 3. Benefits Payable to Couples in 1995 with Identical Total Earnings Through 1994 ${ }^{\mathrm{a}}$

\begin{tabular}{|c|c|c|c|c|}
\hline \multirow[b]{2}{*}{ Couple } & \multirow{2}{*}{$\begin{array}{l}\text { Average } \\
\text { Lifetime } \\
\text { Earnings }^{\mathrm{b}}\end{array}$} & \multicolumn{2}{|c|}{ Social Security Benefits } & \multirow{2}{*}{$\begin{array}{c}\text { Survivor } \\
\text { Benefit/Coup } \\
\text { le Benefit }\end{array}$} \\
\hline & & Couple & $\begin{array}{c}\text { Surviv } \\
\text { or }\end{array}$ & \\
\hline \multicolumn{5}{|l|}{$\begin{array}{l}\text { One } \\
\text { Earner }\end{array}$} \\
\hline Husband & $\$ 60,000$ & $\$ 14,400$ & & \\
\hline Wife & --- & 7,200 & & $2 / 3$ \\
\hline Total & $\$ 60,600$ & $\$ 21,600$ & $\begin{array}{r}\$ 14,40 \\
0\end{array}$ & \\
\hline \multicolumn{5}{|l|}{$\begin{array}{l}\text { Two } \\
\text { Earner }\end{array}$} \\
\hline Husband & $\$ 30,300$ & $\$ 9,636$ & & \\
\hline Wife & $\$ 30,300$ & $\$ 9,636$ & & $1 / 2$ \\
\hline Total & $\$ 60,600$ & $\$ 19,272$ & $\$ 9,636$ & \\
\hline
\end{tabular}

aThis example assumes both the husband and wife are age 65 in 1995 when they retire.

'This example is a one-earner couple, where the husband has earned the taxable maximum over his career, and a two-earner couple who have each earned one-half the taxable maximum. Earnings are assumed to begin at age 22.

Source: Social Security Administration Office of the Actuary, June 1994.

The second couple, in which earnings are equally split, pays the same amount of taxes into the system but receives lower yearly retirement benefits of $\$ 19,272$ while the husband is alive. Each retiree receives an identical retired-worker benefit of $\$ 9,636$. Under current rules, neither would be better off electing toreceive the spouse benefit, which is less than the spouse's own retiredworker benefit ( $\$ 4,818$ versus $\$ 9,636$ in this case) and the spouse must choose one or the other. Furthermore, upon the husband's death the widow can elect to receive either a survivor benefit of $\$ 9,636$, based on her husband's earnings record, or continue to receive her own benefit of $\$ 9,636$, but not both. Hence, benefits for the widow in this "nontraditional family" are only one-half of the already lower total benefits previously paid to the couple. 
Burkhauser \& Smeeding

Not only does a two-earner couple paying the same amount of taxes into the system as a one-earner couple receive a smaller total benefit, but the relative difference in benefits also increases after the death of the husband. These two examples define the extremes of the family payouts implicit in the Social Security benefit structure. A widow whose retired-worker benefit is more than half her husband's retired-worker benefit will receive payments somewhere between these two extremes.

To maintain the same standard of living for the survivor as that previously enjoyed by the couple, using official poverty-line equivalence guidelines, a survivor should receive 80 percent of the previous income going to the couple. Yet we have seen that, at best, Social Security benefits received after a spouse's death are 67 percent of those received by the couple and may drop as low as 50 percent. This has ominous implications for policymakers interested in reducing the disparity between the well-being of women before and after the death of their husbands. Social Security will continue to be the single most important source of income for the majority of retired people (Reno 1993). And the future elderly are much more likely to come from twoearner families in which the woman's retired-worker benefit exceeds her spouse benefit. Hence, on average the rate of Social Security benefits paid after the death of a spouse will continue to decline over the next decades.

This inequity in the Social Security benefit structure has been the subject of several government studies (Committee on Ways and Means 1985; Congressional Budget Office 1986), and several proposals have been made to end it (see, for instance, various authors in Burkhauser and Holden 1982). But reluctance on the part of Congress to either reduce the benefits of one-earner families or raise the taxes necessary to equalize the benefits for two-earner households has stalled a solution. 
Aging Studies Program Policy Brief

\section{A Budget Neutral Proposal for Social Security Reform}

No one consciously "planned" for Social Security to overprotect married couples and underprotect survivors, most of whom are women. But income security policy has consistently offered the greatest level of protection to traditional married men. A traditional male married a younger woman; he is the primary earner in the family; and he dies on average at least a decade before his wife. Hence, in making choices among different ways to expand Social Security protection - an earlier retirement age, higher benefits while both husband and wife are alive, higher benefits to the survivor - the first two have prevailed over the third.

Historically the replacement rate-the amount of wages replaced by Social Security benefits in the first year of retirement-has been the most important measure of Social Security protection. In the early 1970s, Social Security payouts were dramatically enlarged and replacement rates were substantially increased. Thanks in large part to those increases, the poverty rate of older married couples plummeted and, as Tables 1 and 2 suggest, is quite low relative to either older non-married persons or younger households in general. This is true even though the average age at which men receive Social Security benefits has slipped from around age 65 to about age 62 over the last three decades. Since yearly Social Security benefits are actuarially reduced by 20 percent for workers who accept them at age 62, the current level of income security enjoyed by older married couples is even more remarkable. Unfortunately, as we have seen, the tremendous success of Social Security policy in allowing men to retire earlier and still evade poverty during their retirement years has not been shared by their widows.

While there are several methods of dealing with this vulnerability, most of them involve large budgetary outlays (see 
congressional Budget Office 1986). Not all solutions need take this form. The revenue-neutral solution we propose is to shift part of the current benefits going to married couples to survivors. Small reductions in replacement rates at retirement would allow substantial revenues to flow to survivors. Furthermore, part of the drop in the replacement rate could be made up by short delays in retirement by men. Finally, it appears that reducing income to older married couples (who from both a national and crossnational perspective are relatively free of poverty) and redistributing this same income to the survivor (who from both a national and cross-national perspective is least free from poverty) would hurt women little when they are married while helping them substantially when they are survivors and most vulnerable.

- For traditional families (one wage earner and one spouse), we would shift from a two-thirds survivor benefit to a three-quarters survivor benefit. This would mean, for instance, that the survivor of a family receiving $\$ 1,000$ per month when both husband and wife are alive would receive $\$ 750$ per month rather than the current $\$ 667$ per month. This 75 percent survivor benefit would be closer to 80 percent of the couple's combined benefit necessary to keep the survivor at the same equivalent standard of living, consistent with the official poverty equivalence measure discussed above.

- We would change the way Social Security rules currently treat nontraditional families (two earners). As we have seen, a husband and wife who both work, whose worklife earnings are both equal, and whose combined income is the same as that of a traditional husband, pay the same amount of taxes into the Social Security system as the traditional husband. Yet their combined Social Security benefits upon retirement are lower than those paid to the one-earner family. Even worse, with respect to the 


\section{Aging Studies Program Policy Brief}

transition to widowhood, the survivor of this two-worker family on receives 50 percent of their combined joint retirement benefits. We propose to provide survivors of two-earner families the same three-quarters survivor benefit recommended for one-earner families, and base it on the total benefit paid to the couple before the death of the spouse.

Finally, we would change the current way Supplemental Security Income (SSI) treats Social Security benefits by raising the amount of benefits not counted as income from $\$ 20$ per month, the amount set in 1974, to its inflation-adjusted equivalent in 1994 (approximately $\$ 60$ per month) and indexing this protected amount in the future to the inflation rate. This would shelter a larger amount of Social Security benefits from the dollar-fordollar loss in SSI benefits under the current rules. (See Burkhauser and Smeeding 1981 for a fuller discussion of the effect of the interaction of SSI and Social Security on the poor.) This is the most target-efficient way of increasing the income of poor Social Security beneficiaries. In addition, these increases to poor older couples would offset most of the losses related to the payment scheme discussed below.

These proposals could substantially increase the cost of Social Security, depending on how quickly they were phased in. One way to pay the increase would be to raise Social Security taxes, but we favor an alternate proposal. We would hold the total package of Social Security benefits provided to a family constant over the combined lifetime of the couple, but shift some benefits from the period when they are both alive to the period when one is a survivor.

In the long run this could be financed by a change in the formula for adjusting past earnings for inflation. For instance, shifting from a wage-based index to a price-based index would slightly 
reduce the replacement rate for retiring workers over time but would provide the money necessary to fund a three-quarters survivor benefit annuity. Another long-term solution would be to use a less generous benefit formula. Both these benefit-shifting methods would slightly reduce the replacement rate but substantially increase protection for survivors. One way to immediately provide revenues would be to shift the first 1 or 2 percent of future scheduled increases in Social Security benefits that would normally go to offsetting inflation to current survivors.

Our proposals for Social Security reform are in the spirit of the Retirement Equity Act of 1984 (Public Law 98-397) which required employer pensions to pay workers in the form of a joint and last-survivor annuity (pension payments that continue following the death of either the worker or spouse) rather than as a single-life annuity (higher yearly pension payments which end with the death of the worker) unless the worker and the worker's spouse sign a document requesting a single-life annuity. This legislation was passed to encourage workers to shift benefits toward survivors in a revenue-neutral way.

Substantial improvement in the average economic well-being of the aged must not blind us to the fact that our current retirement system has not ended all risks to economic well-being in old age. The dramatic increase in private and public retirement income available for people at older ages has virtually eliminated drops into poverty for married older couples, not only in the first period of retirement but for years after. But it has not meant equivalent protection for surviving spouses, most of whom are women. As women spend more of their lifetime in work outside the home, they will be more likely to earn their own employer or Social Security pensions. But this increase in their direct retirement benefit payments may be considerably offset by the structure of obsolete Social Security payout rules, which no longer reflect the 
Aging Studies Program Policy Brief

changed working patterns of men and women within marriage. It is long past time to address the underprotection of women by our current Social Security system. Our proposals provide a concrete, budget neutral method of substantially reducing the disproportionate risk of poverty faced by older women. 
Burkhauser \& Smeeding

\section{References}

Anderson, Kathryn H., Richard V. Burkhauser, and Joseph F. Quinn. 1986. "Do Retirement Dreams Come True: The Effect of Unanticipated Events on Retirement Plans." Industrial and Labor Relations Review, 39:518-526.

Burkhauser, Richard V., J.S. Butler, and Karen C. Holden. 1991. "How the Death of a Spouse Affects Economic Well-Being After Retirement: A Hazard Model Approach." Social Science Quarterly, 72(3) (September):504-519.

Burkhauser, Richard V. and Karen C. Holden (eds.). 1982. A Challenge to Social Security: The Changing Roles of Women and Men in American Society. New York: Academic Press.

Burkhauser, Richard V. and Timothy M. Smeeding. 1981. "The Net Impact of the Social Security System on the Poor." Public Policy, 29, No. 2 (Spring):159-178.

Committee on Ways and Means, U.S. House of Representatives. 1985. Report on Earnings Sharing Implementation Study. Washington, DC: U.S. Government Printing Office.

Congressional Budget Office, Congress of the United States. 1986. Earnings Sharing Options for the Social Security System. Washington, DC: U.S. Government Printing Office.

Ippolito, Richard A. 1989. Toward Explaining Earlier Retirement after 1970. Pension Benefit Guaranty Corporation Working Paper.

Population Resource Council. 1994. Executive Summary: The Feminization of Aging. Prepared by Nancy Fifield McConnell and reviewed by Cynthia Taeuber, U.S. Bureau of the Census. 
Aging Studies Program Policy Brief

Princeton: Population Resource Center.

Quinn, Joseph F. and Richard V. Burkhauser. 1994. "Retirement and Labor Force Behavior of the Elderly." In Linda Martin and Samuel Preston (eds.), Demography of Aging.

Washington, DC: National Academy of Science, pp. 50-101.

Quinn, Joseph F. and Timothy M. Smeeding. 1993. "The Present and Future Economic Well-Being of the Aged." In Richard V. Burkhauser and Dallas L. Salisbury (eds.), Pensions in a Changing Economy. Washington, DC: NAA/EBRI-ERF Publication, pp. 5-18.

Quinn, Joseph F., Richard V. Burkhauser, and Daniel A. Myers. 1990. Passing the Torch: The Influence of Economic Incentives on Work and Retirement. Kalamazoo, MI: The W.E. Upjohn Institute.

Reno, Virginia F. 1993. "The Role of Pensions in Retirement Income." In Richard V. Burkhauser and Dallas L. Salisbury (eds.), Pensions in a Changing Economy. Washington, DC: NAA/EBRI-ERF Publication, pp. 19-32.

Siegel, Jacob S. and Cynthia M. Taeuber. 1986. "Demographic Dimensions of an Aging Population." In Alan Pifer and Lydia Bronte (eds.), Our Aging Society: Paradox and Promise. New York: W.W. Norton and Co., pp. 79-110.

Smeeding, Timothy M. 1986. "Nonmoney Income and the Elderly: The Case of the "Tweeners." Journal of Policy Analysis and Management, 5:707-724.

Smeeding, Timothy M., Lee Rainwater, and Barbara Boyle Torrey. 1993. "Going to Extremes: An International Perspective on the Economic Status of the U.S. Aged." (May), 
mimeo.

Smolensky, Eugene, Sheldon Danziger, and Peter Gottschalk. 1988. "The Declining Significance of Age in the U.S.: Trends in Well-Being of Children and the Elderly Since 1939." In John L. Palmer, Timothy M. Smeeding, and Barbara Boyle Torrey (eds.), The Vulnerable. Washington, DC: Urban Institute Press, pp. 29-53.

U.S. Congress. 1994. 1994 Green Book: Background Material and Data on Programs within the Jurisdiction of the Committee on Ways and Means. Washington, DC: U.S. Government Printing Office.

U.S. Department of Commerce, Bureau of the Census. 1989. Poverty in the United States, 1987. Washington, DC: U.S. Government Printing Office, Series P-60, No. 163. 